\title{
ANALISIS PENGETAHUAN DAN SIKAP MAHASISWA TENTANG PENGGUNAAN STYROFOAM
}

\author{
Aprilya Dwi Untari ${ }^{1)}$ Yuni Astuti ${ }^{2)}$ \\ ${ }^{1) 2)}$ Pendidikan Biologi FKIP Universitas Muhammadiyah Prof. DR. Hamka \\ email $^{1)}$ : Aprilya.adu@gmail.com \\ email ${ }^{2}$ :yuni.astuti@uhamka.ac.id
}

\begin{abstract}
ABSTRAK: Salah satu wadah makanan yang sering digunakan adalah styrofoam. Styrofoam dijadikan wadah makanan karena ringan, murah, mudah didapat, tidak mudah rusak, tidak perlu dibersihkan, dan dapat langsung dibuang ketika sudah tidak digunakan. Namun, syrofoam berbahaya bagi lingkungan. Penelitian ini bertujuan untuk mengetahui hubungan aspek pengetahuan lingkungan dan sikap mahasiswa mengenai penggunaan styrofoam. Metode penelitian yang digunakan adalah metode deskriptif korelasi. Populasi yang digunakan adalah seluruh mahasiswa FKIP. Sampel yang diteliti berjumlah 100 mahasiswa FKIP. Pengambilan sampel dilakukan dengan teknik Accidental Sampling. Data dianalisis menggunakan uji regresi linear sederhana dan uji korelasi yang sebelumnya dilakukan uji normalitas dan uji linearitas sebagai prasyarat. Uji normalitas dan uji linearitas mendapatkan hasil bahwa data berdistribusi normal dan linear. Uji regresi linear sederhana mendapatkan hasil bahwa terdapat hubungan sebab akibat antara pengetahuan lingkungan terhadap sikap mahasiswa mengenai penggunaan styrofoam. Pada uji korelasi diperoleh nilai signifikansi sebesar $0,000<0,01$, sehingga dapat diartikan bahwa terdapat hubungan antara pengetahuan lingkungan dan sikap mahasiswa mengenai penggunaan styrofoam. Pengetahuan lingkungan berhubungan terhadap sikap mahasiswa dengan tingkat korelasi 0,85. Hasil penelitian dapat disimpulkan bahwa terdapat hubungan yang positif dan sangat kuat antara pengetahuan lingkungan dan sikap mahasiswa mengenai penggunaan styrofoam.
\end{abstract}

\section{Kata kunci: lingkungan, mahasiswa, pengetahuan, sikap, Styrofoam}

\begin{abstract}
One of the most commonly used food containers is styrofoam. Styrofoam is used as a food container because it is light, cheap, easy to obtain, not easily damaged, does not need to be cleaned, and can be immediately discarded when it is out of use. However, styrofoam is harmful to the environment. This research aims to find out the relationship between aspects of environmental knowledge and student attitudes regarding the use of styrofoam. The research method used is a descriptive method of correlation. The population used is all students of FKIP. The sample studied amounted to 100 students of FKIP. Sampling is done by the
\end{abstract}


Accidental Sampling technique. The data were analyzed using simple linear regression tests and correlation tests that had previously performed normality tests and linearity tests as prerequisites. Normality tests and linearity tests get results that the data is distributed normally and linearly. A simple linear regression test found that there was a causal relationship between environmental knowledge and student attitudes regarding the use of styrofoam. In the correlation test, there was a value of significance of $0,000<0,01$, so it can be interpreted that there is a relationship between environmental knowledge and student attitudes regarding the use of styrofoam. Environmental knowledge relates to student attitudes with a correlation rate of 0,85 . The results of the study can be concluded that there is a positive and very strong relationship between environmental knowledge and student attitudes regarding the use of styrofoam.

Keywords: Attitude, environmental, knowledge, students, styrofoam

\section{PENDAHULUAN}

Salah satu wadah makanan yang sering digunakan adalah styrofoam. Styrofoam mengacu pada polystyrene (PS) yang biasa digunakan sebagai wadah makanan atau minuman sekali pakai (Nukmal, Umar, Amanda, \& Kanedi, 2018). Styrofoam dijadikan wadah makanan karena murah, mudah didapat, tidak mudah rusak, tidak perlu dibersihkan, dan dapat langsung dibuang ketika sudah tidak digunakan (Husain, Alalyani, \& Hanga, 2015). Namun, styrofoam juga sangat berbahaya bagi lingkungan. Karuniastuti (2013) styrofoam mengandung zat polystyrene yang harus dihindari. Zat polystyrene dapat mengganggu hormon estrogen pada wanita yang berakibat pada masalah reproduksi, pertumbuhan dan sistem syaraf, tidak baik untuk kesehatan otak, juga styrofoam sulit didaur ulang. Bila didaur ulang, bahan ini memerlukan proses yang sangat panjang dan lama. Azis (2017) menyatakan bahwa benzene tidak bisa dikeluarkan melalui feses atau urin sehingga mengakibatkan penyakit kanker. Salah satu dampak dari penggunaan styrofoam adalah global warming karena senyawa Cloro Fluoro Carbon (CFC) yang dapat menyebabkan efek rumah kaca (Wirahadi, 2017). Penggunaan styrofoam juga berdampak pada meningkatnya limbah mikroplastik di laut. Nurhadi, Budiyantoro, \& Sosiati, (2017) menyatakan bahwa pencemaran dari mikroplastik jenis fragmen dapat bersumber dari kemasan makanan dan tutup botol untuk polimer polystyrene (PS). Mikroplastik memiliki ukuran yang sangat kecil, mikroplastik dapat memasuki dalam tubuh biota laut seperti bivalvia dan ikan, akibatnya mikroplastik dapat masuk ke dalam sistem rantai makanan dan dikonsumsi oleh manusia (Widianarko \& Hantoro, 2018). Styrofoam terbukti sangat berbahaya bagi lingkungan.

Penelitian menganalisa karakteristik, pengetahuan, dan sikap mahasiswa terhadap penggunaan styrofoam. Kondisi ideal yang diharapkan adalah semakin baik pengetahuan lingkungan yang dimiliki maka semakin baik pula sikap mahasiswa mengenai penggunaan styrofoam. Apabila kondisi ideal itu dapat tercapai, maka sampah styrofoam tidak akan semakin banyak dan dapat dikendalikan. 
Penggunaan styrofoam sebagai wadah makanan berdampak pada banyaknya sampah styrofoam. Hasil penelitian Fitidarini \& Damanhuri (2011) mengungkapkan bahwa jumlah berat sampah styrofoam yang dihasilkan rumah makan di kota Bandung adalah sebanyak 2.284 ton/bulan. Styrofoam juga banyak digunakan sebagai wadah makanan di lingkungan FKIP. Berdasarkan hasil observasi yang telah dilakukan Cahyadi, Irnaviola, Farhan, Awalia, \& Asmara (2019) pada tanggal 26 Juni sampai 3 Juli 2019 diperoleh hasil bahwa jumlah berat sampah styrofoam di gedung A sebanyak 21,20 $\mathrm{kg} / \mathrm{bulan}$, sedangkan di gedung $\mathrm{C}$ jumlah berat sampah styrofoam sebanyak 10,56 $\mathrm{kg} /$ bulan. Banyaknya sampah styrofoam ini menunjukkan bahwa banyaknya penggunaan styrofoam sebagai wadah makanan di lingkungan FKIP dan kurangnya sikap mahasiswa terhadap penggunaan styrofoam. Hal tersebut yang mendasari penelitian dengan tujuan untuk mengetahui persepsi mahasiswa terhadap penggunaan styrofoam.

Pengetahuan lingkungan sangat berpengaruh pada sikap mahasiswa. Pengetahuan lingkungan mempengaruhi kesadaran lingkungan karena ketidaktahuan terhadap lingkungan menyebabkan ketidaksadaran pada lingkungan hidup (Darmawan \& Fadjarajani, 2016). Chen (2013) menyatakan bahwa semakin baik pengetahuan lingkungan mahasiswa, maka mahasiswa tersebut akan semakin tahu tentang kualitas produk ramah lingkungan dan tidak akan menggunakan produk yang sulit terurai seperti styrofoam. Selanjutnya hasil penelitian Haryanto, (2014) menunjukkan bahwa pengetahuan lingkungan dapat berpengaruh positif terhadap sikap pada produk ramah lingkungan.

Penelitian Ramadhani, Ardiani, \& Sudaryati (2015) mendapatkan hasil bahwa $65,0 \%$ responden memiliki pengetahuan yang baik tentang kemasan styrofoam dan $82,5 \%$ responden memiliki sikap yang baik tentang kemasan styrofoam. Selanjutnya, penelitian Swamilaksita, Sitoayu, \& Simarmata (2018) menunjukkan bahwa $60,5 \%$ responden dengan pengetahuan yang kurang memiliki perilaku yang kurang terhadap penggunaan styrofoam. Meskipun penelitian yang sedang diteliti memiliki aspek penelitian yang sama (karakteristik, pengetahuan lingkungan, dan sikap) dengan penelitian sebelumnya. Namun, penelitian yang dilakukan berfokus pada dampak styrofoam terhadap lingkungan yang berkaitan dengan pengetahuan lingkungan mahasiswa.

Penelitian ini sangat diperlukan untuk dapat menganalisa persepsi penggunaan styrofoam terhadap kepedulian lingkungan dan melihat hubungan antara sikap dan pengetahuan mahasiswa terhadap penggunaan styrofoam. Informasi yang didapatkan dari penelitian ini dapat digunakan sebagai bahan evaluasi dan upaya bersama antara dosen, mahasiswa, orang tua, dan penyedia untuk meningkatkan pengetahuan lingkungan bersama sehingga dapat memahami dampak lingkungan tentang peenggunaan styrofoam.

\section{METODE PENELITIAN}

Jenis penelitian ini adalah penelitian kuantitatif. Penelitian ini menggunakan metode deskriptif korelasi. Penelitian dilakukan di salah satu perguruan tinggi swasta di Jakarta pada bulan Januari hingga Agustus 2020. Sampel terdiri dari 100 mahasiswa. Teknik pengambilan sampel menggunakan Accidental Sampling.

Prosedur penelitian dibagi menjadi tiga tahap yaitu tahap persiapan, tahap pelaksanaan, dan tahap akhir. Kegiatan pada tahap persiapan meliputi studi pendahuluan, membuat kisi-kisi instrumen, membuat instrumen, validasi ahli beserta revisi, dan 
uji coba penelitian. Pada tahap pelaksanaan dilakukan kegiatan pengaturan jadwal kegiatan dan pengambilan data penelitian. Selanjutnya, pada tahap akhir dilakukan kegiatan pengumpulan data penelitian menjadi satu, pengolahan data penelitian, analisis data, dan merumuskan kesimpulan.

Instrumen yang digunakan berupa kuesioner yang terdiri dari 28 butir pertanyaan/pernyataan yang diisi oleh mahasiswa dengan cara menceklis salah satu jawaban yang dianggap sesuai dengan kondisi mahasiswa tersebut. Analisa data dilakukan dengan uji regresi linear sederhana dan uji korelasi dengan menggunakan aplikasi SPSS.

Aspek pengetahuan lingkungan dan sikap mahasiswa memiliki kriteria penilaian. Kriteria untuk nilai pengetahuan lingkungan dan sikap mahasiswa dapat dilihat pada Tabel 1.

Tabel 1. Kriteria Nilai Pengetahuan dan Sikap

\begin{tabular}{cccc}
\hline \multicolumn{2}{c}{$\begin{array}{c}\text { Kriteria Nilai } \\
\text { Pengetahuan }\end{array}$} & \multicolumn{2}{c}{ Kriteria Nilai Sikap } \\
Interval & Predikat & Interval & Predikat \\
\hline $81-100$ & Tinggi & $91-100$ & Sangat Baik \\
$65-80$ & Sedang & $76-90$ & Baik \\
$50-64$ & Rendah & $61-75$ & Cukup \\
& & $\leq 60$ & Kurang
\end{tabular}

(Sumber: Permendikbud 81A, 2013; SK Dirjen Mandikdasmen Nomor 12/C/Kep/TU, 2008)

\section{HASIL DAN PEMBAHASAN}

\section{a. Deskripsi Data}

Data penelitian diperoleh dengan memberikan kuesioner kepada 100 responden, yaitu mahasiswa FKIP yang berada di lingkungan FKIP. Data penelitian meliputi aspek pengetahuan dan sikap mahasiswa mengenai penggunaan Styrofoam.

\section{1) Aspek Pengetahuan Mahasiswa terhadap Penggunaan Styrofoam}

Indikator dalam aspek pengetahuan lingkungan tentang penggunaan styrofoam meliputi "karakteristik styrofoam", "simbol, pernyataan", “istilah", dan "dampak senyawa berbahaya yang terdapat pada styrofoam terhadap lingkungan". Nilai ratarata untuk aspek pengetahuan dapat dilihat pada Gambar 1.

Gambar 1: Aspek Pengetahuan Mahasiswa terhadap Penggunaan Styrofoam

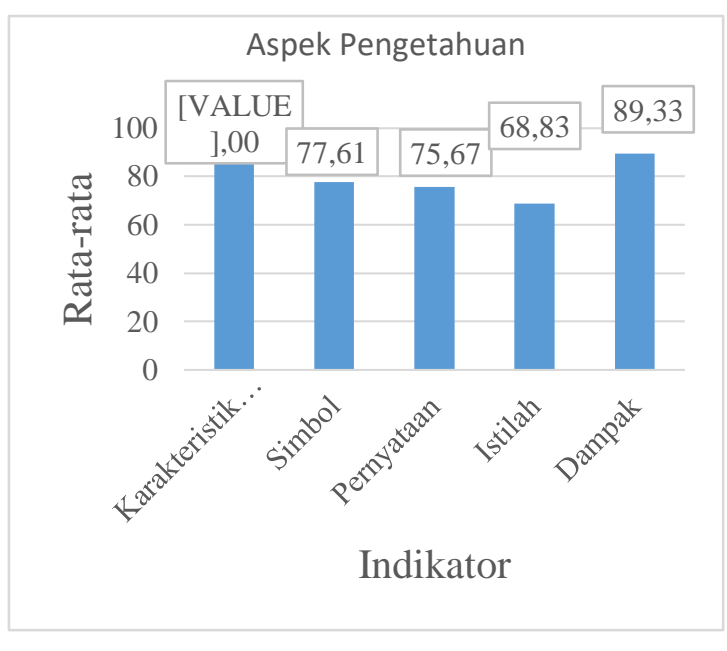

Data pada Gambar 1 menunjukkan bahwa indikator "karakteristik styrofoam" memiliki nilai rata-rata tertinggi, yaitu sebesar 91,00 dengan predikat tinggi. Hal ini berbeda dengan indikator "istilah" yang memperoleh nilai rata-rata terendah, yaitu sebesar 68,83 dengan predikat sedang. Aspek pengetahuan lingkungan mahasiswa dengan indikator "karakteristik styrofoam" dan "dampak" dikategorikan tinggi dengan nilai masing-masing 91,00 dan 89,33. Sedangkan indikator "simbol", "pernyataan", dan "istilah" tentang isu lingkungan yang terkait dengan styrofoam

Bio-Lectura: Jurnal Pendidikan Biologi, Vol 7, No 2, Oktober 2020 
dinilai sedang dengan perolehan nilai berturut-turut adalah 77,$60 ; 75,67$; dan 68,83 .

\section{2) Aspek Sikap Mahasiswa tentang Penggunaan Styrofoam}

Data pada Gambar 2 menunjukkan bahwa sikap mahasiswa pada indikator "tingkat kekhawatiran mahasiswa terhadap kondisi lingkungan", "tingkat kontribusi mahasiswa dalam menjaga lingkungan", "tingkat kepedulian masyarakat terhadap lingkungan", dan "tingkat kepedulian pemerintah terhadap upaya pelestarian lingkungan" dikategorikan baik dengan perolehan nilai berturut-turut sebesar 90,00; 83,$67 ; 82,33$; dan 82,83. Hal ini berbeda dengan indikator "tingkat kepedulian mahasiswa terhadap isu lingkungan" yang memperoleh nilai rata-rata terkecil, yaitu sebesar 72,17 dengan predikat cukup.

Gambar 2: Aspek Sikap Mahasiswa tentang Penggunaan Styrofoam

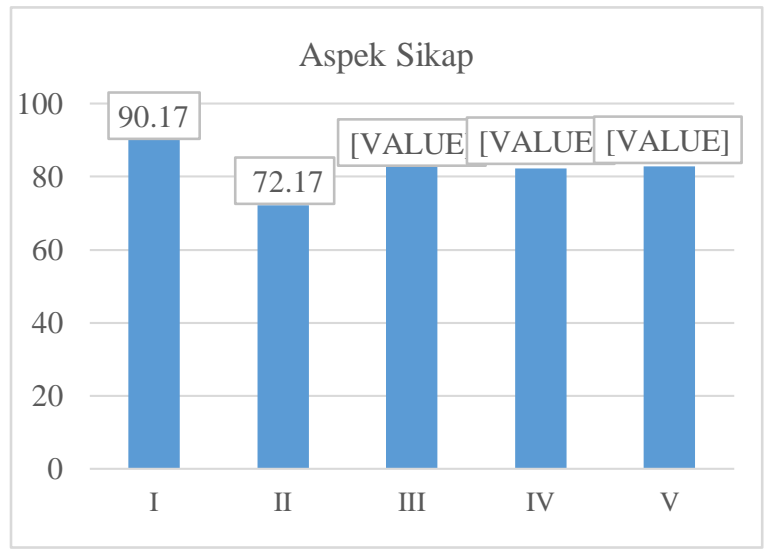

Keterangan:

I =Tingkat kekhawatiran pengguna terhadap kondisi lingkungan

$\mathrm{II}=$ Tingkat kepedulian pengguna terhadap isu lingkungan
III=Tingkat kontribusi pengguna dalam menjaga lingkungan

IV=Tingkat kepedulian masyarakat terhadap lingkungan

$\mathrm{V}=$ Tingkat kepedulian pemerintah terhadap upaya pelestarian lingkungan

\section{3) Hubungan Aspek Pengetahuan dengan Sikap Mahasiswa tentang Penggunaan Styrofoam}

Uji regresi linear sederhana diperlukan untuk mengukur besarnya hubungan sebab akibat antara aspek pengetahuan lingkungan dengan aspek sikap mahasiswa mengenai penggunaan styrofoam.

Tabel 2. Model Summary untuk Aspek Pengetahuan dan Sikap Mahasiswa tentang Penggunaan Styrofoam

\begin{tabular}{lcccc}
\hline M & R & R Square & $\begin{array}{l}\text { Adj R } \\
\text { Square }\end{array}$ & Std. Error \\
1 & $.850^{\mathrm{a}}$ & .723 & .720 & 1.38 \\
\hline a. Predictors: (Constant), Pengetahuan \\
b. Dependent Variable: Sikap
\end{tabular}

Keterangan:

$\mathrm{R}=$ nilai korelasi

$\mathrm{R}$ Square $=$ koefisien diterminasi

Tabel 2 menunjukkan besarnya nilai korelasi (R) sebesar 0,850 dan koefisien determinasi ( $\mathrm{R}$ square) sebesar 0,723. Hal ini bermakna bahwa terdapat hubungan sebab akibat antara pengetahuan lingkungan terhadap sikap mahasiswa adalah sejumlah $72,3 \%$.

Tabel 3. Nilai F Hitung untuk Aspek Pengetahuan dan Sikap Mahasiswa tentang Penggunaan Styrofoam 


\begin{tabular}{lcrccc}
\hline Model & Sum of & df & Mean & F & Sig. \\
& Squares & & Square & & \\
Regr & 486.752 & 1 & 486.752 & 255.9 & $.00^{\text {b }}$ \\
Res & 186.408 & 98 & 1.902 & & \\
Tot & 673.160 & 99 & & & \\
\hline
\end{tabular}

a. Dependent Variable: Sikap

b. Predictors: (Constant), Pengetahuan

Dari Tabel 3 didapatkan bahwa nilai

F hitung sejumlah 255,900 dengan tingkat signifikansi $0,000<0,01$. Maka terdapat hubungan sebab akibat antara pengetahuan lingkungan terhadap sikap mahasiswa mengenai penggunaan styrofoam.

Diketahui nilai constant (a) sejumlah 4,008, sedangkan nilai pengetahuan (b / koefisien regresi) sejumlah 0,618 , sehingga persamaan regresinya adalah $\mathrm{Y}=4,008+$ $0,618 X$. Persamaan ini bermakna, konstanta 4,008 mengandung arti bahwa nilai konsisten variabel sikap mahasiswa sejumlah 4,008. Koefisien regresi $X$ sejumlah 0,618 mengemukakan bahwa setiap peningkatan $1 \%$ nilai pengetahuan lingkungan, maka nilai sikap mahasiswa meningkat sejumlah 0,618. Koefisien regresinya bernilai positif, sehingga arah pengaruh pengetahuan lingkungan terhadap sikap mahasiswa adalah positif.

Pada Tabel 4 diperoleh nilai signifikansi sejumlah $0,000<0,01$, sehingga dapat ditetapkan bahwa pengetahuan lingkungan memiliki hubungan sebab akibat terhadap sikap mahasiswa mengenai penggunaan styrofoam.
Tabel 5. Coefficients untuk Aspek Pengetahuan dan Sikap Mahasiswa tentang Penggunaan Styrofoam

\begin{tabular}{|c|c|c|c|c|c|}
\hline \multirow[t]{2}{*}{ Model } & \multicolumn{2}{|c|}{$\begin{array}{c}\text { Unstand } \\
\text { Coeff }\end{array}$} & $\begin{array}{l}\text { Stand } \\
\text { Coeff }\end{array}$ & $\mathrm{t}$ & Sig. \\
\hline & B & $\begin{array}{l}\text { Std. } \\
\text { Error }\end{array}$ & Beta & & \\
\hline (Constant) & 4.09 & 1.30 & & $\begin{array}{r}3.1 \\
4\end{array}$ & .002 \\
\hline Pengetahuan & .618 & .039 & .850 & 16 & .000 \\
\hline
\end{tabular}

a. Dependent Variable: Sikap

Tabel 6. Uji Korelasi untuk Aspek Pengetahuan dan Sikap Mahasiswa tentang Penggunaan Styrofoam

\begin{tabular}{llrr}
\hline & \multicolumn{2}{c}{$\begin{array}{c}\text { Pengeta } \\
\text { huan }\end{array}$} \\
& & \multicolumn{1}{c}{ Sikap } \\
\multirow{2}{*}{ Pengetahu } & Pearson Corr & 1 & $.850^{* *}$ \\
an & Sig. (2-tailed) & & .000 \\
& N & 100 & 100 \\
\multirow{2}{*}{ Sikap } & Pearson Corr & $.850^{* *}$ & 1 \\
& Sig. (2-tailed) & .000 & \\
& N & 100 & 100 \\
\hline
\end{tabular}

Dari Tabel 6 didapat nilai signifikansi sebesar $0,000<0,01$, sehingga dapat diartikan bahwa terdapat hubungan antara pengetahuan dan sikap mahasiswa tentang penggunaan styrofoam. Pengetahuan berhubungan secara positif terhadap sikap dengan tingkat korelasi sangat kuat $(0,85)$. Tingkat korelasi sangat kuat yaitu antara 0,80-1,00.

\section{b. Pembahasan}

Data penelitian meliputi aspek pengetahuan dan sikap mahasiswa terhadap penggunaan styrofoam. Data pada Gambar 1 menunjukkan bahwa pengetahuan tentang 
"karakteristik styrofoam" dikategorikan tinggi dengan nilai rata-rata sebesar 91,00. Hal ini karena mahasiswa memiliki pengetahuan yang memadai mengenai bahaya styrofoam jika digunakan pada makanan bersuhu tinggi dan bahaya warna putih susu pada styrofoam. Pernyataan tersebut senada dengan Mukminah (2019) bahwa wadah styrofoam bersifat karsinogenik dan semakin berbahaya jika digunakan pada makanan bersuhu tinggi. Styrofoam sering kali dipanaskan dalam microwafe sehingga menimbulkan suhu yang sangat tinggi. Ini berbahaya karena dapat menimbulkan racun (Farrelly \& Shaw, 2017). Wirahadi (2017) menyatakan warna putih susu pada styrofoam berasal dari polystyrene yang dicampur dengan seng dan butadien sehingga kehilangan sifat jernihnya.

Pengetahuan tentang indikator "istilah" memiliki nilai rata-rata terendah, yaitu sebesar 68,83 dengan predikat sedang. Hal ini karena mahasiswa kurang mengenal dan memahami istilah-istilah yang digunakan, seperti biodegradable dan zero waste. Hasil tersebut senada dengan penelitian Sumarsono \& Giyatno (2012) bahwa kurangnya pemahaman mahasiswa diprediksi karena kurangnya pengetahuan mahasiswa mengenai istilah-istilah yang terdapat pada kemasan serta tidak adanya penjelasan mengenai efek bahan kimia tersebut bagi lingkungan. Intan \& Rijati (2019) menyatakan bahwa masih banyak mahasiswa yang belum mengenal istilah zero waste, maka dari itu perlu diadakan sosialisasi dan gerakan zero waste di kalangan mahasiswa. Nizar, Munir, Munawar, Irvan, \& Waller (2018) bahwa konsep zero waste belum banyak digunakan di Indonesia. Konsep zero waste perlu digunakan di Indonesia karena menawarkan pengelolaan sampah secara holistik, mulai dari penghindaran sampah, daur ulang, dan pemulihan material bekas.
Data pada Gambar 2. menunjukkan bahwa indikator "tingkat kekhawatiran mahasiswa terhadap kondisi lingkungan" dikategorikan sangat baik dengan perolehan nilai rata-rata sebesar 90.17. Hal ini karena mahasiswa sudah terbiasa membawa wadah minuman atau tumbler. Hasil tersebut serupa dengan penelitian Sumarsono \& Giyatno (2012) bahwa sebagian besar mahasiswa membawa tempat minum atau tumbler dengan tujuan untuk berhemat dan ikut membantu dalam menjaga lingkungan. Gallego-Schmid, Mendoza, \& Azapagic, (2019) mahasiswa menggunakan tumbler karena lebih hemat dan dapat digunakan berulang kali.

Sementara itu, indikator "tingkat kepedulian mahasiswa terhadap isu lingkungan" memperoleh nilai rata-rata terkecil, yaitu sebesar 72,17 dengan predikat cukup. Hal ini karena pengetahuan dan kepedulian mahasiswa mengenai isu lingkungan hidup masih minim. Hasil tersebut serupa dengan penelitian Zulfa, Max, Hukum, \& Ilyas (2016) bahwa mayoritas mahasiswa masih memahami isuisu lingkungan hanya di permukaan saja sehingga cenderung kurang peduli terhadap isu lingkungan yang ada. Janmaimool \& Chudech (2020) bahwa rasa kepedulian dan tanggung jawab mahasiswa terhadap isu-isu lingkungan masih rendah.

Pada Tabel 6 diperoleh nilai signifikansi sebesar $0,000<0,01$, yang bermakna terdapat hubungan antara pengetahuan dan sikap mahasiswa tentang penggunaan styrofoam. Pada Tabel 6 didapatkan tingkat korelasi sebesar 0,85 yang menandakan kedua variabel tersebut memiliki korelasi yang positif dan sangat kuat. Hasil serupa terdapat pada penelitian Swamilaksita, Sitoayu, \& Simarmata (2018) bahwa $60,5 \%$ mahasiswa dengan pengetahuan lingkungan rendah memiliki sikap yang kurang terhadap penggunaan

Bio-Lectura: Jurnal Pendidikan Biologi, Vol 7, No 2, Oktober 2020 
styrofoam. Sarkawi (2015) menyakatan bahwa pengetahuan lingkungan yang baik akan meningkatkan sikap dan kesadaran lingkungan seseorang. Kirmani \& Khan, (2016) menunjukkan bahwa pengetahuan lingkungan memiliki hubungan yang signifikan dan positif terhadap sikap mahasiswa dan penggunaan produk ramah lingkungan. Hal ini karena terdapat korelasi yang positif dan sangat kuat antara pengetahuan lingkungan dan sikap mahasiswa mengenai penggunaan styrofoam.

\section{KESIMPULAN}

Hasil penelitian menunjukkan terdapat hubungan yang positif dan sangat kuat antara pengetahuan lingkungan dan sikap mahasiswa mengenai penggunaan styrofoam. Informasi yang didapatkan dari penelitian dapat digunakan sebagai bahan evaluasi dan upaya bersama antara dosen, mahasiswa, orang tua, serta penyedia untuk meningkatkan pengetahuan lingkungan bersama sehingga dapat memahami dampak lingkungan terhadap penggunaan styrofoam.

\section{REFERENSI}

Azis, R. A. (2017). Penggunaan Styrofoam Pada Kemasan Pangan Sebagai Pelanggaran Terhadap Hak Konsumen ( Studi Kasus Pada Sd Swasta Unwanus Saadah Jakarta Utara ). Lex Jurnalica, 14. Retrieved from https://ejurnal.esaunggul.ac.id/index.ph p/Lex/article/viewFile/2074/1797

Cahyadi, A., Irnaviola, B., Farhan, M., Awalia, N., \& Asmara, S. (2019). Hasil Observasi Styrofoam.

Chen, L. (2013). A Study of Green Purchase Intention Comparing with Collectivistic
(Chinese) and Individualistic (American) Consumers in Shanghai, China. Information Management and Business Review, 5(7), 342-346. https://doi.org/ISSN 2220-3796

Darmawan, D., \& Fadjarajani, S. (2016). Hubungan antara pengetahuan dan sikap pelestarian lingkungan dengan perilaku wisatawan dalam menjaga kebersihan lingkungan. 4(24), 37-49. Retrieved from http://jurnal.unsil.ac.id/index.php/geogr afi/article/viewFile/87/57

Farrelly, T. A., \& Shaw, I. C. (2017). Polystyrene as Hazardous Household Waste. Household Hazardous Waste Management. https://doi.org/10.5772/65865

Fitidarini, N. L., \& Damanhuri, E. (2011). Timbulan Sampah Styrofoam di Kota Bandung. Jurnal Teknik Lingkungan, 17(2), 87-97.

Gallego-Schmid, A., Mendoza, J. M. F., \& Azapagic, A. (2019). Environmental impacts of takeaway food containers. Journal of Cleaner Production, 211(March 2019), 417-427. https://doi.org/10.1016/j.jclepro.2018.1 1.220

Haryanto, B. (2014). The Influence of Ecological Knowledge and Product Attributes in Forming Attitude and Intention to Buy Green Product. International Journal of Marketing Studies, 6(2), 83-91. https://doi.org/10.5539/ijms.v6n2p83

Husain, I., Alalyani, M., \& Hanga, A. H. (2015). Disposable plastic food container and its impacts on health. The Journal of Energy and Environmental Science, 130(12), 618-623. https://doi.org/ISJN: 4382-1729 
Intan, T., \& Rijati, S. (2019). Kampanye Zero Waste Sebagai Gaya Hidup Pada Mahasiswa dan Ibu Rumah Kampanye Zero Waste Sebagai Gaya Hidup Pada Mahasiswa Dan Ibu Rumah Tangga Di Jatinangor ( Analisis Situasional Dan Rencana Solusi ). 4(March), 4-13. https://doi.org/ISSN: 2502 - 7034

Janmaimool, P., \& Chudech, S. (2020). Effect of domestic and global environmental events on environmental concern and environmental responsibility among university students. Sustainability (Switzerland), 12(4), https://doi.org/10.3390/su12041610

Karuniastuti， N. (2013). Bahaya Plastik terhadap Kesehatan dan Lingkungan. Swara Patra: Majalah Pusdiklat Migas, 3(1), 6-14. Retrieved from http://ejurnal.ppsdmmigas.esdm.go.id/s p/index.php/swarapatra/article/view/43/ 65

Kirmani, M. D., \& Khan, M. N. (2016). Environmental concern to attitude towards green products: Evidences from India. Serbian Journal of Management, 11(2), 159-179. https://doi.org/10.5937/sjm11-9241

Menteri Pendidikan. (2013). : Permendikbud 81A. Jakarta.

Mukminah, I. Al. (2019). Bahaya Wadah Styrofoam dan Alternatif Penggantinya. Farmasetika.Com (Online), 4(2), 3234.

https://doi.org/10.24198/farmasetika.v4 i2.22589

Nizar, M., Munir, E., Munawar, E., Irvan, \& Waller, V. (2018). Applying Zero Waste Management Concept in a City of Indonesia: A Literature Review. International Journal of Engineering \&Technology, 7(4), 6109-6114. https://doi.org/10.14419/ijet.v7i4.23127

Nukmal, N., Umar, S., Amanda, S. P., \& Kanedi, M. (2018). Effect of styrofoam waste feeds on the growth, development and fecundity of mealworms (Tenebrio molitor). OnLine Journal of Biological Sciences, 18(1), 24-28.

https://doi.org/10.3844/ojbsci.2018.24. 28

Nurhadi, T., Budiyantoro, C., \& Sosiati, H. (2017). Identifikasi Mechanical Properties Dari Bahan Daur Ulang Polystyrene. 1(1), 36-40. Retrieved from http://journal.umy.ac.id/index.php/jmp $\mathrm{m} \% 0 \mathrm{AI}$

Ramadhani S, P., Ardiani, F., \& Sudaryati, E. (2015). Gambaran Pengetahuan dan Sikap dengan Posisi Tawar Konsumen tentang Penggunaan Kemasan Styrofoam sebagai Wadah Makanan di Amaliun Foodcourt. Gizi, Kesehatan Reproduksi Dan, 1-8. Retrieved from http://jurnal.usu.ac.id/index.php/gkre/ar ticle/view/12365

Sarkawi, D. (2015). Volume XVI Nomor 02 September 2015 ISSN 1411-1829. Pendidikan Lingkungan Dan Pembangunan Berkelanjutan, XVI(September), 101-114. https://doi.org/10.21009/PLPB

SK Dirjen Mandikdasmen Nomor 12/C/Kep/TU. (2008). Retrieved from http://slideplayer.info

Sumarsono, \& Giyatno, Y. (2012). Analisis Sikap Dan Pengetahuan Konsumen Terhadap Ecolabelling Serta Pengaruhnya Pada Keputusan Pembelian Produk Ramah Lingkungan. Business and Management Journal, 15(1), 70-85. Retrieved from www.menlh.go.id

Bio-Lectura: Jurnal Pendidikan Biologi, Vol 7, No 2, Oktober 2020 
Swamilaksita, P. D., Sitoayu, L., \& Simarmata, N. (2018). Knowledge, Attitude, and Behavior of Housewives in Using Styrofoam Packaging in West Jakarta. KnE Life Sciences, 4(5), 627. https://doi.org/10.18502/kls.v4i5.2592

Widianarko, B., \& Hantoro, I. (2018). Mikroplastik Mikroplastik dalam Seafood Seafood dari Pantai Utara Jawa. Retrieved from www.unika.ac.id

Wirahadi, M. (2017). Elemen Interior Berbahan Baku Pengolahan Sampah Styrofoam Dan Sampah Kulit Jeruk. None, 5(2), 144-153. Retrieved from https://media.neliti.com/media/publicati ons/100549-ID-elemen-interiorberbahan-baku-pengolahan.pdf

Zulfa, V., Max, M., Hukum, I., \& Ilyas, I. (2016). Isu-Isu Kritis Lingkungan Dan Perspektif Global. Jurnal Green Growth Dan Manajemen Lingkungan, 5(1), 29-40. https://doi.org/10.21009/jgg.051.03 